\title{
Gastric Cardia Carcinoma
}

National Cancer Institute

\section{Source}

National Cancer Institute. Gastric Cardia Carcinoma. NCI Thesaurus. Code C6794.

A carcinoma that arises from the gastric cardia. 